\title{
Micropropagation and Cryopreservation of Sultani fig (Ficus carica L.) genotype
}

\section{El-Homosany A. Abd El-Wahab and Hossam A. Sayed}

National Gene Bank and Genetic Resources (NGBGR), ARC, Giza, Egypt

Received: 20 August 2019/Accepted 15 Oct. 2019/Publication date: 25 Oct. 2019

\begin{abstract}
This study was conducted to asses shoots micropropagation and cryopreservation of Sultani fig genotype. For shoots proliferation, explants (apical buds) cultured on MS medium supplemented with $0.5 \mathrm{mgl}^{-1} \mathrm{Kin}$. resulted the highest shoot length $(3.66 \mathrm{~cm})$ and shoots number/explant $(2.83)$. The highest rooting percentage $(75.00 \%)$, root length $(2.4 \mathrm{~cm})$ and root numbers $(4.08)$ were obtained on half strength MS medium containing $0.5 \mathrm{mgl}^{-1}$ NAA. Ex vitro rooting of fig plantlets was successfully acclimatized on mixture of Peatmoss : Sand (1:1) with success rate of $75.00 \%$. Cryopreservation using vitrification procedure, shoot tips were treated with Plant Vitrification Solution $2\left(\mathrm{PVS}_{2}\right)$ at $0^{\circ} \mathrm{C}$ for $(30$, 40 and 50) minutes and plunged into Liquid Nitrogen (LN), the results obtained from vitrification experimental part showed that survival and regrowth rates were varied with time of loading $\mathrm{PVS}_{2}$ and the maximum of survival $(50.00 \%)$ and regrowth rates were recorded $(25.00 \%)$ had in shoot tips after 40 min. exposure to $\mathrm{PVS}_{2}$.
\end{abstract}

Keywords: Cryopreservation, fig, micropropagation, vitrification

\section{Introduction}

The common fig (Ficus carica, L.) family Moraceae, is one of the few deciduous species in the genus Ficus. Such species is subtropical and dicotyledonous. F. carica has been cultivated for a long time in various places worldwide for its edible fruit. Remnants of figs has been found in excavations of sites dating as far back as at least 5,000 B.C. F. carica was presumed to originate from Western Asia and spread to the Mediterranean by humans (California Rare Fruit Growers, Inc. 1996). Low water required crops are an important need concerning shortage in water resources in arid and semi-arid zones. One of these crops is Ficus carica L. There is a major interest in increasing fig-cultivated area in Egypt since it is one of the traditional Mediterranean crops has a high nutrient value. In order to achieve this target, there is a need to get rapid plant cloning for producing sufficient number of fig seedlings. Biotechnology tools can play this role and provide a rapid method for plant mass propagation (Pasqual and Ferreira, 2007).

Previous studies on the micropropagation in different fig cultivars have reported successful shoot regeneration by Bayoudh et al., (2015) who developed a protocol for rapid in vitro propagation with shoot tips of three major Tunisian local fig (Ficus carica L.) varieties Zidi, Soltani, Bither Abiadh and one rare and recalcitrant caprifig Assafri. Shahcheraghi and Shekafandeh (2016) showed that the highest shoot numbers per explant (13.67 and 8.8) were achieved eight weeks after second subculture in 'Runu' and 'Bargchenari' genotypes respectively, when Murashige and Skoog (MS) medium supplemented with $0.5 \mathrm{mgl}^{-1}$ Benzyl Adenine (BA) and $0.2 \mathrm{mgl}^{-1} \mathrm{~N} 6$-(2-isopentenyl) adenine (2ip). In 'Dehdez' genotype, the number of shoots was 4.4 per explant, when culture media were supplemented with $6.0 \mathrm{mgl}^{-1}$ Kinetin (Kin) and $0.2 \mathrm{mgl}^{-1}$ NAA. The highest root numbers (2.23) were obtained in 'Bargchenari' genotype on half strength MS medium containing $1.5 \mathrm{mgl}^{-1} \mathrm{IBA}$.

Cryopreservation provides the only realistic option for the long-term in vitro storage of vegetatively propagated plant genetic resources (Lynch et al., 2007). Cryopreservation is a part of biotechnology. Biotechnology plays an important role in international plant conservation programs and in preservation of the world's genetic resources (Bajaj, 1995; Benson, 1999). Therefore, establishment of fig germplasm long-term preservation is a major purpose to make fig germplasm available for research.

Cryopreservation by vitrification method have been developed to improve the regrowth of vitrified plant tissues (Sakai et al., 1990; Langis and Steponkus, 1990; Towill 1990; Matsumato et al.,

Corresponding Author: El-Homosany A. Abd El-Wahab, National Gene Bank and Genetic Resources (NGBGR), ARC, Giza, Egypt. E-mail: a-homos2007@hotmail.com 
1995; Hirai and Sakai, 1999; Lambardi et al., 2000; Leunufna and Keller, 2005) but the results vary. A vitrification solution designated as PVS2 was found to be suitable for many species of plants (Sakai et al., 1991; Towill and Jerett, 1992; Niino et al., 1992; Brison et al., 1995). This solution dehydrates cells osmotically at nonfreezing temperature; hence, cells are subjected to osmotic stress. The cytoplasm then becomes more viscous, a state necessary for vitrification (no crystallization) to occur (Sinniah and Gantait, 2013). Nevertheless, chemical toxicity and excessive osmotic stress may occur to the cells when overexposed to PVS2 (Hong et al., 2009). Hence, it was essential to determine the most suitable dehydration period for Ficus carica shoot tips to obtain sufficient dehydration for vitrification to occur and at the same time to avoid the toxic effects of the solution.

The objective of this research was to study the micropropagation of Sultani fig (Ficus carica) through tissue culture technique and cryopreservation of shoot tips through vitrification technique.

\section{Materials and Methods}

This study was carried out at the In vitro Storage Plant and Cryopreservation Laboratory at National Gene Bank, Agricultural Research Center Giza, Egypt during the period from 2018 to 2019.

\section{Source of plant material}

Cuttings of one Egyptain Ficus carica L. genotype Sultani, were collected on December 2017 from a germplasm collection at Siwa Oasis from different location and propagated the cuttings as mother plant in greenhouse at National Gene Bank, Agricultural Research Center, Giza.

\section{A. In Vitro propagation.}

\section{Surface sterilization of explants.}

Small cutting portions were washed under running tap water for about one hour, with 3 drops of Dettol next, the sterilization of the one nodal cutting were carried out in laminar air flow hood condition with $70 \%$ ethanol for 2 minutes followed by $10 \%$ sodium hypochlorite $(\mathrm{NaClO}$, chlorox $5.2 \%$ ) for 12 minutes. The explants was rinsed seven times with sterile distilled water to remove traces of Clorox completely. After two successive rinses with sterile distilled water, each for $3 \mathrm{~min}$.

\section{Media composition and culture conditions.}

Fig sterilized buds were placed on solid MS medium (Murashige and Skoog, 1962) as a basal medium supplemented with $0.2 \mathrm{mgl}^{-1} \mathrm{BA}, 30 \mathrm{~g} / \mathrm{L}$ sucrose and $7 \mathrm{~g} / \mathrm{L}$ agar according to Mustafa and Taha (2012) during the establishment stage. The $\mathrm{pH}$ of the medium was adjusted to 5.7 and autoclaved at $121^{\circ} \mathrm{C}$ and $15 \mathrm{Ib}$ lin for 20 minutes. The cultured explants were incubated under 16 hours of artificial light (fluorescent light at $30 \mu \mathrm{M} / \mathrm{sec}$ ) and 8 hours of darkness at average temperature $23 \pm 2^{\circ} \mathrm{C}$. After one-month, shoots were cultured on different media.

\subsection{Multiplication Stage}

Effect of MS medium supplemented with BA or Kin at 0.5 or $1.0 \mathrm{mgl}^{-1}$ were tested to find out the best growth regulators that encourages the highest multiplication rate. Proliferated shoots obtained were monthly subculture in $350 \mathrm{~mL}$ glass jars containing the same medium for three months.

\subsection{Rooting stage}

Proliferated shoots about $2 \mathrm{~cm}$ in length were transferred to glass jars $350 \mathrm{~mm}$ filled with $25 \mathrm{ml}$ of rooting medium which consisted of half strength MS medium plus 3\% sucrose, $0.7 \%$ agar and supplemented with 0.5 or $1.0 \mathrm{mgl}^{-1}$ of IBA and NAA alone.

\subsection{Acclimatization stage}

Rooted shoots were rinsed carefully with sterile distilled water to remove adhering medium and put it in a fungicide $\left(1.0 \mathrm{gl}^{-1}\right)$ for $2 \mathrm{~min}$. before transplanting into plastic $10 \times 15 \mathrm{~cm}$. pots filled with a mixture of Peatmoss : Sand (1:1 by volume) and covered with clear plastic bags then maintained in growth chamber (22 ${ }^{\circ} \mathrm{C} \pm 1$ ) for 3 weeks before being transferred to the greenhouse with artificial lighting, and $80 \%$ relative humidity for 8 weeks. 


\section{B. In vitro Cryopreservation using vitrification technique.}

\section{Plant material, vitrification procedure and culture conditions.}

Shoot tips 2-3 mm long were excised and precultured for four days at $25^{\circ} \mathrm{C}$ in dark on the basal MS medium without plant growth regulators and supplemented with $0.3 \mathrm{M}$ sucrose. Then shoot tips were treated with a mixture of $2 \mathrm{M}$ glycerol plus $0.4 \mathrm{M}$ sucrose in MS medium Loading Solution (LS) for $20 \mathrm{~min}$ at $25{ }^{\circ} \mathrm{C}$ before being dehydrated with a highly concentrated vitrification solution $\mathrm{PVS}_{2}$ $\left(\mathrm{PVS}_{2}\right.$ contains 30\% (w/v) glycerol, 15\% (w/v) Ethylene Glycol (EG), 15\% (w/v) Dimethyl Sulfoxide (DMSO) and 0.4 M sucrose in MS medium and $\mathrm{pH}$ was adjusted at 5.8 according to Sakai et al., (1990). Shoot tips were dehydrated with $\mathrm{PVS}_{2}$ at $0^{\circ} \mathrm{C}$ for 30,40 and $50 \mathrm{~min}$. The $\mathrm{PVS}_{2}$ was then replaced with $0.6 \mathrm{ml}$ of fresh chilled $\mathrm{PVS}_{2}$ solution and the cryotubes were directly plunged into LN. After at least one hour, shoot tips were rapidly thawed at $40^{\circ} \mathrm{C}$ (one min.), after which $\mathrm{PVS}_{2}$ was drained from the cryotubes and replaced with unloading solution of liquid MS medium containing 1.2 M sucrose (Sakai et al., 1991) at $25^{\circ} \mathrm{C}$ for $20 \mathrm{~min}$. and finally cultured into petri dishes containing $15 \mathrm{ml}$ of recovery medium containing full strength MS medium supplemented with $30 \mathrm{gl}^{-1}$ sucrose, $1.0 \mathrm{mgl}^{-1} \mathrm{BA}, 0.1 \mathrm{mgl}^{-}$ ${ }^{1}$ IBA and $7.0 \mathrm{gl}^{-1}$ agar. Survival and recovery percentages of the shoot tips were observed after 8 weeks.

\section{Statistical Analysis}

Recorded data were statistically analyzed by one way ANOVA using MSTAT-C program. Factorial experiments were designed to quantify the plant growth regulators (PGRs) added. Seven parameters were registered: Shoot length $(\mathrm{cm})$, Number of shoots, rooting $(\%)$, root length, Number of roots, survival (\%) after cryopreservation and regrowth (\%). Each parameters was analyzed by one way analysis of variance (ANOVA), followed by least significant difference (LSD) test according to Snedecor and Cochran (1982). The significance of difference among means was analyzed using LSD test at $\mathrm{p}<0.05$.

\section{Results and Discussion}

\section{Effect of different cytokinin concentrations on proliferation stage.}

In regard to shoot multiplication data in Table (1) revealed that medium supplemented with 0.5 $\mathrm{mgl}^{-1}$ Kin resulted the highest shoot length $(3.66 \mathrm{~cm})$. No significant differences were noticed between shoot length on medium with the other cytokinin concentrations $\left(1.0 \mathrm{mgl}^{-1} \mathrm{Kin}, 0.5 \mathrm{mgl}^{-1} \mathrm{BA}\right.$ or 1.0 $\mathrm{mgl}^{-1} \mathrm{BA}$ ) which showed length $1.39,1.08$ and $0.96 \mathrm{~cm}$ respectively.

As for to the effect of cytokinin concentrations results indicated that medium with $0.5 \mathrm{mgl}^{-1} \mathrm{Kin}$ showed the highest shoots number/explant (2.83), followed significantly by medium with $0.5 \mathrm{mgl}^{-1} \mathrm{BA}$ (2.25 shoots/explant). While, medium with $1.0 \mathrm{mgl}^{-1} \mathrm{Kin}$ medium with $1.0 \mathrm{mgl}^{-1} \mathrm{BA}$ gave the lowest shoots number/explant (1.58 and 1.25) without significant difference between them.

Table 1: Effect of different cytokinin concentrations on shoot proliferation of Sultani fig genotype.

\begin{tabular}{lcc}
\hline Treatment & Shoot length $(\mathbf{c m})$ & No. of shoots \\
\hline Kinetin at $\mathbf{0 . 5} \mathbf{~ m g l}^{-\mathbf{1}}$ & $3.66 \mathrm{~A}$ & $2.83 \mathrm{~A}$ \\
Kinetin at $\mathbf{1 . 0} \mathbf{~ m g l}^{-1}$ & $1.39 \mathrm{~B}$ & $1.58 \mathrm{C}$ \\
BA at $\mathbf{0 . 5} \mathbf{~ m g l}^{-\mathbf{1}}$ & $1.08 \mathrm{~B}$ & $2.25 \mathrm{~B}$ \\
BA at $\mathbf{1 . 0} \mathbf{~ m g l}^{\mathbf{1 1}}$ & $0.96 \mathrm{~B}$ & $1.25 \mathrm{C}$ \\
\hline
\end{tabular}

Mean followed by the same letter(s) in each column are not significantly different from each other at $5 \%$ level.

\section{Effect of auxin type and concentration added to half strength MS medium on rooting.}

Concerning the effect of adding different auxin concentrations to half strength MS medium on rooting percentage, data of Table (2) show that medium with $0.5 \mathrm{mgl}^{-1} \mathrm{NAA}$ resulted the highest insignificant rooting percentage $(75.00 \%)$, followed without significant differences by rooting percentage on half strength MS medium with $0.5 \mathrm{mgl}^{-1} \mathrm{IBA}(66.66 \%), 1.0 \mathrm{mgl}^{-1} \mathrm{IBA}$ or $1.0 \mathrm{mgl}^{-1} \mathrm{NAA}$ which showed the same rooting percentage $(50.00 \%)$.

Results in Table (2) about the effect of different auxin concentrations on main root length $(\mathrm{cm})$ showed that half strength MS medium with $0.5 \mathrm{mgl}^{-1}$ NAA produced the highest main root length (2.40 
$\mathrm{cm}$ ), followed without significant differences by main root length on half strength MS medium with 0.5 $\mathrm{mgl}^{-1}$ IBA $(1.57 \mathrm{~cm})$. Half strength MS medium with $1.0 \mathrm{mgl}^{-1} \mathrm{IBA}$ or $1.0 \mathrm{mgl}^{-1} \mathrm{NAA}$ produced the lowest main root length (1.29 and $1.20 \mathrm{~cm}$ respectively) without significant differences in-between.

With regard to the effect of different auxin concentrations on number of roots/shoot, results in Table (2) appeared that half strength MS medium with $0.5 \mathrm{mgl}^{-1} \mathrm{NAA}$ showed the highest significant number of roots/shoot (4.08), followed without significant differences by number of roots/ shoot on half strength MS medium with $0.5 \mathrm{mgl}^{-1}$ IBA (2.79). Half strength MS medium with $1.0 \mathrm{mgl}^{-1} \mathrm{NAA}$ or 1.0 $\mathrm{mgl}^{-1}$ IBA produced the lowest number of roots/shoot (1.83 and 1.33) without significant differences between them.

Table 2: Effect of different auxins concentrations added to half strength MS medium on rooting of Sultani fig genotype.

\begin{tabular}{lccc}
\hline \multicolumn{1}{c}{ Treatments } & Rooting \% & Root length (cm) & No. of roots \\
\hline IBA at $\mathbf{0 . 5} \mathbf{~ m g l}^{\mathbf{1}}$ & $66.66 \mathrm{~A}$ & $1.57 \mathrm{AB}$ & $2.79 \mathrm{AB}$ \\
IBA at $\mathbf{1 . 0} \mathbf{~ m g l}^{-1}$ & $50.00 \mathrm{~A}$ & $1.29 \mathrm{~B}$ & $1.33 \mathrm{~B}$ \\
NAA at $\mathbf{0 . 5} \mathbf{~ m g l}^{-1}$ & $75.00 \mathrm{~A}$ & $2.40 \mathrm{~A}$ & $4.08 \mathrm{~A}$ \\
NAA at $\mathbf{1 . 0} \mathbf{~ m g l}^{-1}$ & $50.00 \mathrm{~A}$ & $1.20 \mathrm{~B}$ & $1.83 \mathrm{~B}$ \\
\hline
\end{tabular}

Mean followed by the same letter(s) in each column are not significantly different from each other at $5 \%$ level.

\section{Acclimatization stage}

Survival percentage of rooted Sultani fig plantlets after acclimatization for 8 weeks were clear that all in vitro rooted shoots of acclimatization in the greenhouse where survival percentage reached up to $75.00 \%$.

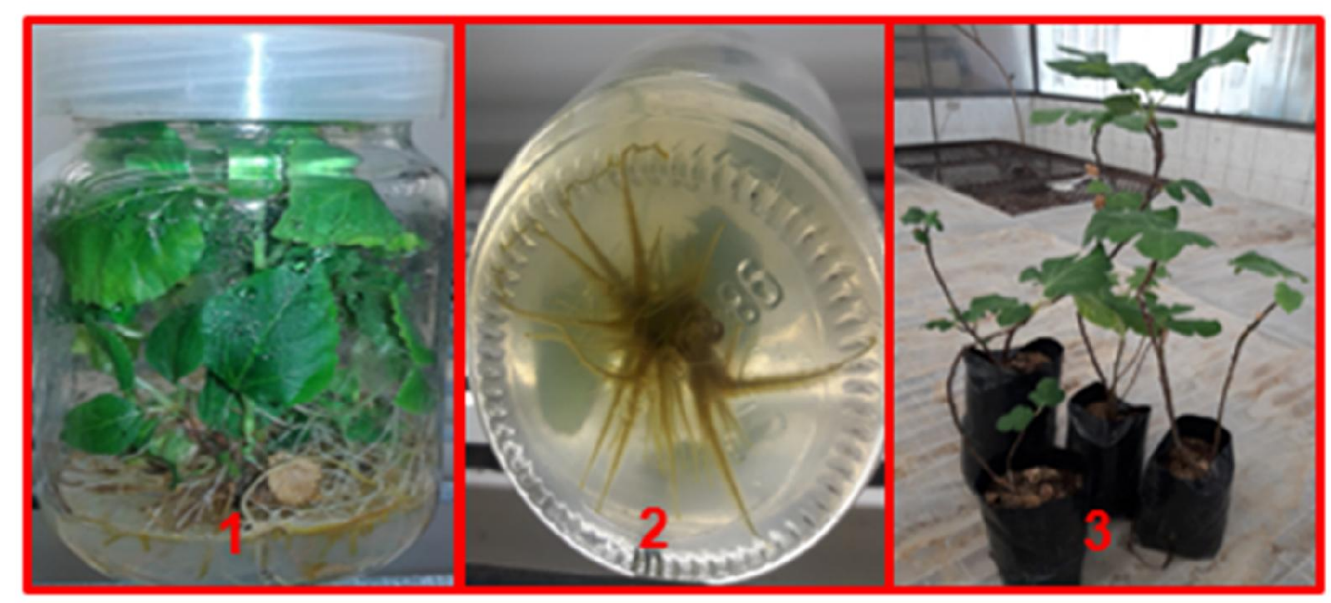

Fig. 1. Micropropagation of Sultani fig genotype

1-Multiplication stage on MS medium contained $0.5 \mathrm{mgl}^{-1} \mathrm{Kin}$

2- Rooting stage on half strength MS medium contained $0.5 \mathrm{mgl}^{-1} \mathrm{NAA}$

3- Acclimatization stage on medium contained Peatmoss : Sand (1:1)

Summarize the main results. Our results are in agreement with those of Fràguas et al., (2004) who optimized an in vitro propagation protocol for Ficus carica cv. 'Roxo de Valinhos' by the regular strength of Woody Plant Medium (WPM) in combination with $0.5 \mathrm{mgl}^{-1}$ kinetin which gave the best condition for shoot proliferation plants. While, the inclusion of BA in the medium induced excessive callus formation as well as small and vitrified shoots. Mustafa et al., (2013) reported on two fig cultivars (Sultany and Aboudi) produced the highest number of induced shoots and leaf from shoot tips explants with the values of 23.79 and 4.29 respectively in full MS media supplemented with as low as $0.5 \mathrm{mgl}^{-}$ ${ }^{1}$ BA. Also, Bayoudh et al., (2015) revealed that the variety Soltani showed the proliferation rate (16.91 branches per plant) and plantlet development were provided with culture on MS medium containing 0.5 $\mathrm{mgl}^{-1} \mathrm{BA}$ and $0.1 \mathrm{mgl}^{-1} \mathrm{NAA}$. The best rooting rate $(83.34 \%$ ) was favored on half strength MS medium 
and $1.0 \mathrm{mgl}^{-1}$ Indole-3-Butyric Acid (IBA). Ex vitro rooting of fig plantlets was successfully performed on moist peat with success rate of $90 \%$.

These results differed from the observation by Danial et al., (2014) who reported a maximum 5 shoots per explant was successfully induced in MS medium containing $3.0 \mathrm{mgl}^{-1} \mathrm{BA}$ via shoot tips of Ficus carica L. A study by Darwesh et al., (2014) showed that, $5.0 \mathrm{mgl}^{-1} \mathrm{BA}$ and $1.0 \mathrm{mgl}^{-1} \mathrm{GA}$ (gibberellic acid) supplemented in MS medium induced a significant increment of shoot number in Ficus carica. They concluded that BA was the most efficient cytokinin in enhancing shoot proliferation of Ficus carica L. via shoot tips cultures. Wan et al., (2018) who cultured Ficus carica cv. Japanese BTM 6 on MS media supplemented with different concentrations of BA $\left(0,0.5,1.0,1.5\right.$, and $2.0 \mathrm{mgl}^{-}$ ${ }^{1}$ ). Of all the treatments of BA, MS media containing with $2.0 \mathrm{mgl}^{-1} \mathrm{BA}$ marked the highest number of shoots per explant with the average value of $1.67 \pm 0.33$ while 1.5 and $2.0 \mathrm{mgl}^{-1}$ of BA produced the highest differences in shoot height with $0.51 \pm 0.08 \mathrm{~cm}$ and $0.51 \pm 0.07 \mathrm{~cm}$ after twelve weeks respectively. While, MS media with $0.5 \mathrm{mgl}^{-1} \mathrm{BA}$ produced lower response of shoot and leaf induction. These differences in the concentration of BA used may be due to the difference in cultivar as variations in the genetic make-up determines the response or interaction between plant growth regulators and endogenous growth regulators of the plant (Verma et al., 2009).

\section{Effect of cryopreservation of shoot tips on survival and regrowth.}

\section{Survival percentage.}

Concerning the effect of the vitrification solution $\left(\mathrm{PVS}_{2}\right)$ and liquid nitrogen (LN) on survival percentage of shoot tip explants, survival were ranged from $50-91.67 \%$ for the non-LN with significant differences among 30, 40 and 50 minutes of $\mathrm{PVS}_{2}$ exposure (Fig 2). However, after LN exposure, shoot tips treated with $\mathrm{PVS}_{2}$ for 40 min gave the highest survival percentage $(50 \%)$ with significant differences among all treatments after cryopreservation. While, the lowest survival percentage of shoot tips was observed (25.00 and 16.67\%) after 30 and $50 \mathrm{~min}$ exposure to pvs 2 respectively, without significant differences between them.

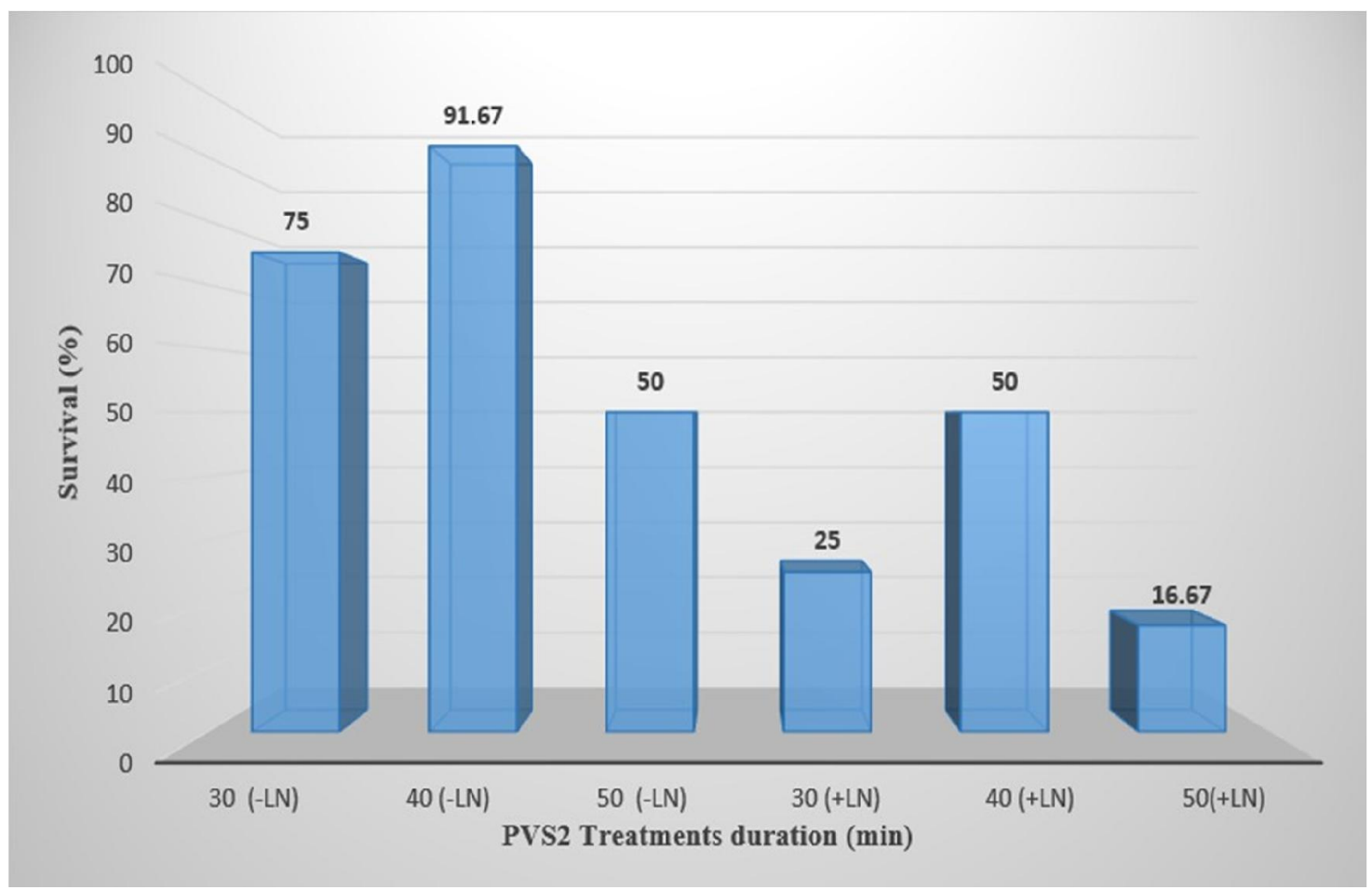

Fig. 2: Effect of pvs 2 and cryopreserved in liquid nitrogen on survival percentage of Sultani fig shoot tip explants 


\section{Regrowth percentage.}

Concerning the effect of the vitrification solution $\left(\mathrm{PVS}_{2}\right)$ and liquid nitrogen $\left(-196^{\circ} \mathrm{C}\right)$ on regrowth percentage of shoot tip explants, data in Fig (3) showed that the highest regrowth was $(75.00 \%$ and $72.22 \%$ ) for the non-liquid nitrogen for 40 and $30 \mathrm{~min}$ of exposure time respectively, without significant differences between them, this percentage reduced to $(25.00 \%)$ with shoot tips treated with pvs $_{2}$ for $50 \mathrm{~min}$. without liquid nitrogen. However, after LN exposure, shoot tips treated with $\mathrm{PVS}_{2}$ for $40 \mathrm{~min}$ gave the highest regrowth percentage $(25.00 \%)$ with significant differences among all treatments after cryopreservation. This regrowth decreased to $8.34 \%$ when shoot tips were incubated in the $\mathrm{pvs}_{2}$ for $30 \mathrm{~min}$. While, shoot tips failed to regrowth $(00.00 \%)$ when applying a $50 \mathrm{~min}$ to $\mathrm{pvs}_{2}$ after cryopreservation with liquid nitrogen.

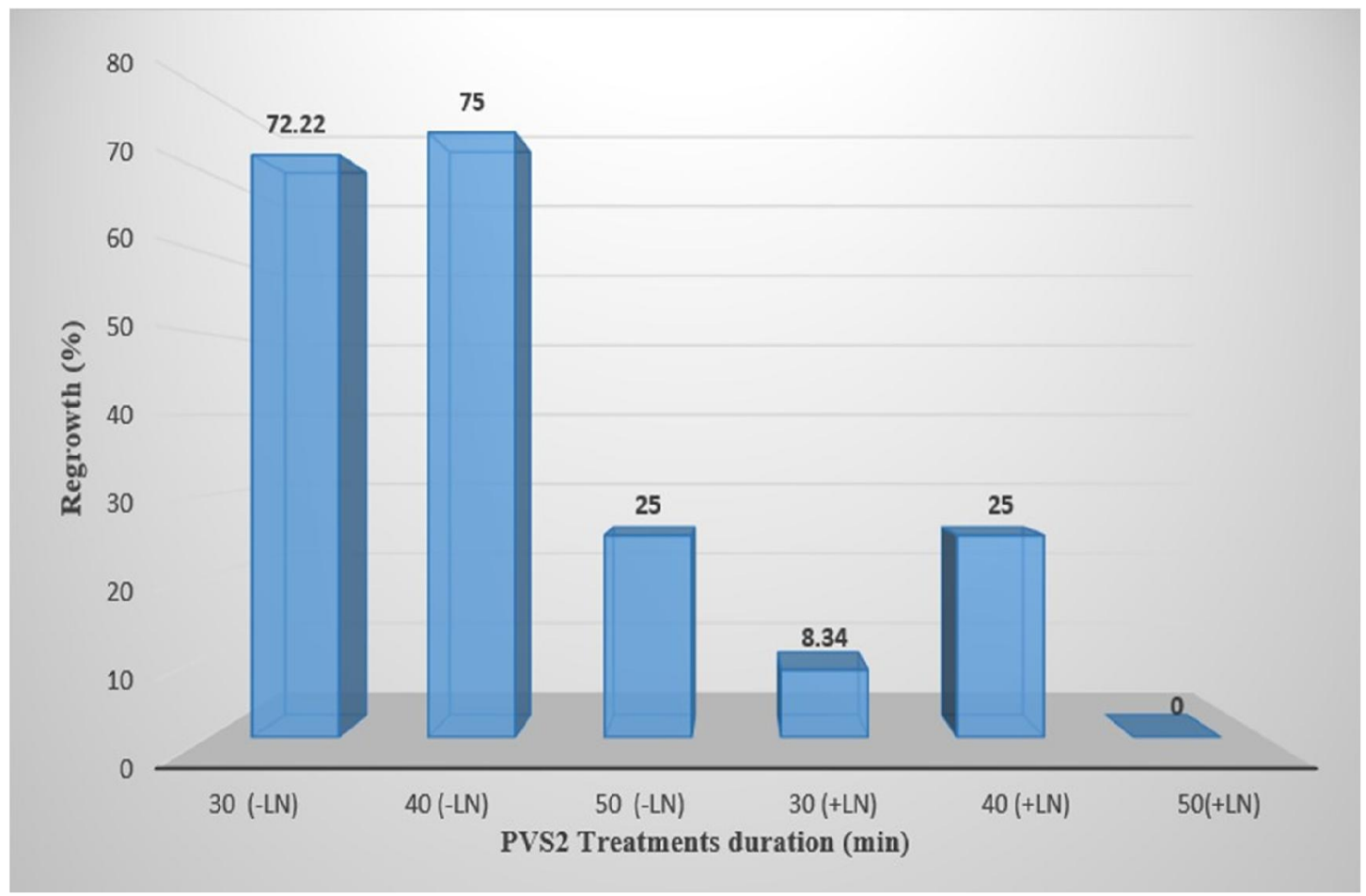

Fig. 3: Effect of $\mathrm{pvs}_{2}$ and cryopreserved in liquid nitrogen on regrowth percentage of Sultani fig shoot tip xplants.

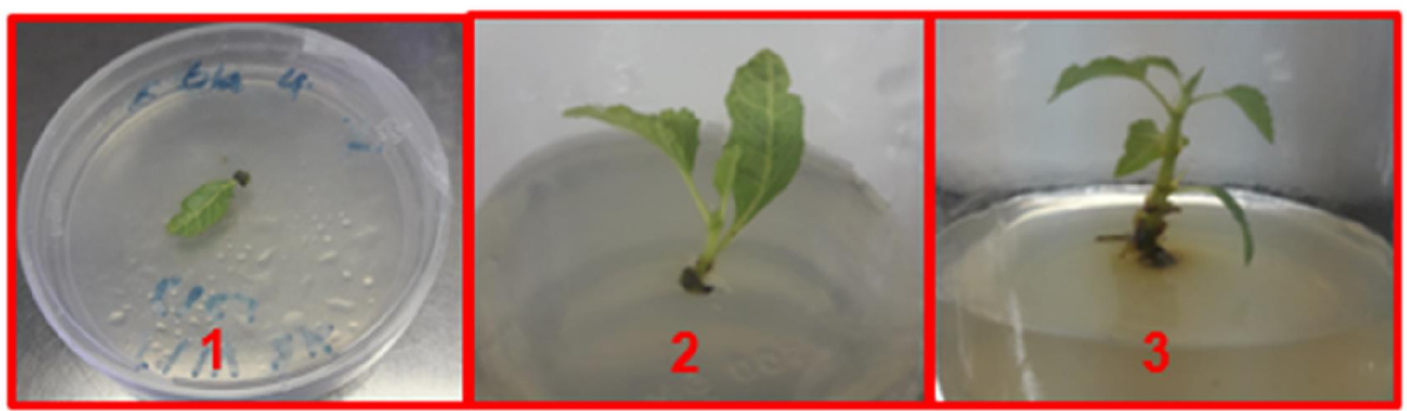

Fig. 4: Regrowth of Sultani fig shoot tips after cryopreservation for 40 days $^{(1)}, 70$ days $^{(2)}$ and 90 days ${ }^{(3)}$.

Studies on cryopreservation of Ficus carica have not been reported thus far. In the present study, shoot tips of Ficus carica L. Sultani genotype when exposed to protectant solution $\left(\mathrm{PVS}_{2}\right)$ for different periods of time (less or more than $40 \mathrm{~min}$ ) were found to be relatively affected by decreased the survival and regrowth of the shoot tips. Similar finding was reported by Sakai et al. (1991) on nuceller cells of naval orange. But the effect of exposure time to $\mathrm{PVS}_{2}$ was found to be species specific as there are 
reports of high survival rate at 3 hours exposure to $\mathrm{PVS}_{2}$ solution (Ishikawa et al., 1997). Also, Yamada et al. (1991) obtained $80 \%$ regeneration when the apical meristem exposed to $\mathrm{PVS}_{2}$ for $5 \mathrm{~min}$. at $25^{\circ} \mathrm{C}$ or for $15 \mathrm{~min}$. at $0^{\circ} \mathrm{C}$. When shoot tips of papaya were exposed to $100 \% \mathrm{PVS}_{2}$ for different durations of time, there were differences observed in the recovery rates of the shoot tips. The best rate of recovery was $70 \%$ for the tips that had been exposed to $100 \% \mathrm{PVS}_{2}$ for 20 minutes at $0{ }^{\circ} \mathrm{C}$. No recovery occurred post cryopreservation with exposure to $\mathrm{PVS}_{2}$ for 10 minutes or 60 minutes, suggesting that time of exposure to $\mathrm{PVS}_{2}$ was critical to cryopreservation success. In addition, shoot tips of papaya (Carica papaya L.) in Australia were successfully cryopreserved by Azimi et al. (2005) who revealed that the duration of exposure to vitrification solution was varied and $70 \%$ recovery was obtained from the shoot tips which had been exposed to $100 \% \mathrm{PVS}_{2}$ for 20 minutes at $0{ }^{\circ} \mathrm{C}$. Treatments for less than 20 minutes or more than 40 minutes resulted in no regeneration after liquid nitrogen (LN) treatment.

In the vitrification protocol, an optimum dehydration with a highly concentrated vitrification solution $\left(\mathrm{PVS}_{2}\right)$ is the key step for producing high levels of recovery growth after cryopreservation. Properly dehydrated shoot tips show less injury due to an overexposure to the $\mathrm{PVS}_{2}$ solution during dehydration and increase the ability to be vitrified upon rapid cooling into LN, thereby avoiding the risk of intracellular freezing. To optimize the exposure time to $\mathrm{PVS}_{2}$ solution, we treated excised shoot tips with the PVS2 solution for 30 to $50 \mathrm{~min}$ at $0^{\circ} \mathrm{C}$ prior to a plunge into LN. As shown in Fig. (2) shoot survival depended upon the length of the exposure to the PVS2 solution. The highest shoot survival (about 50\%) was obtained when the shoot tips were dehydrated with PVS2 solution for $40 \mathrm{~min}$.

These preliminary results show the potentiality of the application of micropropagation and the vitrification technique for the conservation of fig genetic resources. However, it is necessary to increase recovery by optimization of the protocol applying different time $\mathrm{PVS}_{2}$ exposures, pre-culturing and recovering conditions. Further study is still required to evaluate genetic stability of stored cryogenic plant tissues.

\section{References}

Azimi, M., C. O. Brien, S. Ashmore and R. Drew, 2005. Cryopreservation of Papaya Germplasm. Acta Hort. 692, ISHS.43-50.

Bajaj, Y. P. S., 1995. Cryopreservation of plant cell, tissue and organ culture for the conservation of germplasm and biodiversity. In: Bajaj YPS (ed) Biotechnology in Agriculture and Forestry Cryopreservation of Plant Germplasm I, New York, Springer-Verlage, pp. 3-18.

Bayoudh, C. H., R. Labidi, A. Majdoub and M. Mars, 2015. In vitro Propagation of caprifig and female fig varieties (Ficus carica L.) from Shoot tips. J. Agr. Sci. Tech. Vol. 17: 1597-1608.

Benson, E. E. (1999). Cryopreservation. In: Benson EE (ed) Plant Conservation Biotechnology, Taylor and Francis, London, pp. 83-95.

Brison, M., M.T. de bougaud and F. Dosba, 1995. Cryopreservation of in vitro grown shoot tips of two interspecific Prunus rootstocks. Plant Sci. 105: 235-242.

California Rare Fruit Growers, Inc., 1996. Fig Fruit Facts. The Fullerton Arboretum, CSUF, Fullerton, CA. Available:

Danial, G. H., D. A. Ibrahim, S. A. Brkat and B. M. Khalil, 2014. Multiple shoots production from shoot tips of fig tree (Ficus carica L.) and callus induction from leaf segments. International Journal of Pure and Applied Sciences and Technology 20(1): 117-124.

Darwesh, H. Y., S. A. Bazaid and B. N. A. Samra, 2014. In vitro propagation method of Ficus carica at Taif governorate using tissue culture technique. International Journal of Advanced Research 2(6): 756-761.

Fraguas, C.B., M. Pasqual, L.F. Dutra and J.O. Cazetta, 2004. Micropropagation of fig (Ficus carica L.) 'Roxo de Valinhos' plants. In Vitro Cell Develop. Biol. Plant, 40: 471-474.

Hirai, D. and A. Sakai, 1999. Cryopreservation of in vitro grown meristems of potato (Solanum tuberosum L.) by encapsulation vitrification. Potato Res 42:153-160.

Hong, S., M. Yin, X. Shao, A. Wang and W. Xu, 2009. Cryopreservation of embryogenic callus of Dioscorea bulbifera by vitrification. Cryo Letters, 30: 64-75.

Ishikawa, K., K. Harata and M. Mii, 1997. Cryopreservation of zygotic embryos of a Japanese terrestrial orchid (Bletilla striata) by vitrification. Plant Cell Rep., 16:754-757. 
Lambardi, M. A. Fabbri and A. Caccavale, 2000. Cryopreservation of white poplar (Populus alba L.) by vitrification of in vitro grown shoot tips. Plant Cell Rep 19:213-218.

Langis, R. and P. L. Steponkus, 1990. Cryopreservation of rye protoplasts by vitrification. Plant Physiol. 92:666-671.

Leunufna, S. and E. R. J. Keller, 2005. Cryopreservation of yams using vitrification modified by including droplet method: Effects of cold acclimation and sucrose. Cryo Letters 26 (2): 93-102.

Lynch, P. T., E. E. Benson and K. Harding, 2007. Invited Commentary Climate change: the role of ex situ and cryo-conservation in the future security of economically important, vegetatively propagated plants. Journal of Horticultural Science and Biotechnology. 82: 157-160.

Matsumoto, T. A. Sakai and K. Yamada, 1995. Cryopreservation in vitro grown apical meristems of lily by vitrification. Plant Cell Tissue Organ Cult 41:237-241.

Murashige, T. and F. Skoog, 1962. A revised medium for rapid growth and bioassays with tobacco tissue cultures. Physiol. Plant., 15: 473-497.

Mustafa, N. S. and R. A. Taha, 2012. Influence of plant growth regulators and subculturing on in vitro multiplication of some fig (Ficus carica) cultivars. Journal of Applied Sciences Research. 8(8): 4038-4044.

Mustafa, N. S., R. A. Taha, S. A. M. Hassan and N. S. Zaied, 2013. Effect of medium strength and carbon source on in vitro shoot multiplication of two Ficus carica cultivars. Journal of Applied Sciences Research 9(4): 3068-3074.

Niino, T., A. Sakai, H. Yakuwa and K. Nojiri, 1992. Cryopreservation of in vitro grown shoot tips of apple and pear by vitrification. Plant Cell Tissue Org. Cult. 28: 261-266.

Pasqual, M. and E. A. Ferreira, 2007. Micropropagation of Fig Tree (Ficus carica sp). Protocols for Micropropagation of Woody Trees and Fruits, pp: 409-416.

Sakai, A., S. Kobayashi and I. Oiyama, 1990. Cryopreservation of nucellar cells of navel orange $(C$. sinensis Osb. Var. brasliiensis) by vitrification. Plant Cell Rep. 9:30-33.

Sakai, A., S. Kobayashi and I. Oiyama, 1991. Survival by vitrification of nucellar cells of navel orange (C. sinensis Osb. Var. brasliiensis Tanaka) colled to $-196^{\circ} \mathrm{C}$. J. Plant Physiol. 137: 463-470.

Shahcheraghi, S. T. and A. Shekafandeh, 2016. Micropropagation of three endemic and endangered fig (Ficus carica L.) genotypes. Adv. Hort. Sci., 30(3): 129-134.

Sinniah, U. R. and S. Gantait, 2013. Cryopreservation of immature Parkia speciosa Hassk. zygotic embryonic axes following desiccation or exposure to vitrification solution. Acta Physiologiae Plantarum, 35: 2629-2634.

Snedecor, C. W. and W. G. Cochran, 1982. Statistical Methods. 7th Ed. The lowa State University in Ames, Iowa, USA.

Towill, L. E., 1990. Cryopreservation of isolated mint shoot tips by vitrification. Plant Cell Rep 9:178180

Towill, L. E. and R. T. Jarret, 1992. Cryopreservation of sweet potato [Ipomoea batatas (L) Lam] shoot tips by vitrification. Plant Cell Rep 11: 175-178.

Verma, A., C. P. Malik, V. K. Gupta and Y. K. Sinsinwar, 2009. Response of groundnut varieties to plant growth regulator (BAP) to induce direct organogenesis. World Journal of Agricultural Sciences 5(3): 313-317.

Vidal, N., C. Sánchez, L. Jorquera, A. Ballester and A. M. Vieitez, 2005. Cryopreservation of chestnut by vitrification of in vitro- grown shoot tips. In vitro Cell Dev. Biol. Plant. 41: 63-68.

Wan, T. L., C.L. Fui, Y.L. Wei, S. Sreeramanan and L.C. Bee, 2018. Shoot Induction from Axillary Shoot Tip Explants of Fig (Ficus carica) cv. Japanese BTM 6. Tropical Life Sciences Research, 29(2): 165-174.

Yamada, T., A. Sakai, T .Matsumura and S. Higuchi, 1991. Cryopreservation of apical meristems of white clover (Trifolium repens L.) by vitrification. Plant Science. 78:81-87. 